\title{
Kimchi cabbage (Brassica rapa L.) by-products treated with calcium oxide and alkaline hydrogen peroxide as feed ingredient for Holstein steers
}

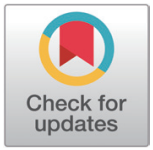

Received: Mar 31, 2021

Revised: May 4, 2021

Accepted: May 12, 2021

${ }_{\text {These authors contributed equally to }}$ this work.

${ }^{*}$ Corresponding author Sang-Suk Lee

Ruminant Nutrition and Anaerobe Laboratory, Department of Animal Science and Technology, Sunchon National University, Suncheon 57922 Korea.

Tel: +82-61-750-3237

E-mail: rumen@scnu.ac.kr

Copyright @ 2021 Korean Society of Animal Sciences and Technology. This is an Open Access article distributed under the terms of the Creative Commons Attribution Non-Commercial License (http:// creativecommons.org/licenses/by$\mathrm{nc} / 4.0 /$ ) which permits unrestricted non-commercial use, distribution, and reproduction in any medium, provided the original work is properly cited.

ORCID

A-Rang Son

https://orcid.org/0000-0002-3896-0950

\author{
A-Rang Son ${ }^{1 \#}$, Seon-Ho Kim ${ }^{1 \#}$, Raniel A. Valencia ${ }^{1,2,3}$, Chang-Dae Jeong ${ }^{1}$, \\ Mahfuzul Islam ${ }^{1}$, Chul-Ju Yang ${ }^{2,4}$ and Sang-Suk Lee ${ }^{1 *}$ \\ ${ }^{1}$ Ruminant Nutrition and Anaerobe Laboratory, Department of Animal Science and Technology, \\ Sunchon National University, Suncheon 57922, Korea \\ 2Interdisciplinary Program in IT-Bio Convergence System (BK 21 plus), Sunchon National University, \\ Suncheon 57922, Korea \\ ${ }^{3}$ Department of Animal Science, College of Agriculture, Central Luzon State University, Science City of \\ Muñoz 3120, Philippines \\ ${ }^{4}$ Animal Nutrition and Feed Science Laboratory, Department of Animal Science and Technology, \\ Sunchon National University, Suncheon 57922, Korea
}

\section{Abstract}

This study aimed to investigate the effects of Kimchi cabbage by-products either treated or untreated with calcium oxide $(\mathrm{CaO})$ and alkaline hydrogen peroxide (AHP) as substitutional ingredient of total mixed ration (TMR) on in vitro fermentation, in situ disappearance and growth performance of Holstein steers. Cannulated Holstein $(600 \pm 47 \mathrm{~kg})$ was used for both the in vitro and in situ experiments. The treatments used were TMR only (CON), TMR $+30 \%$ Kimchi cabbage by-products fresh matter (FM) basis (TC), TMR $+30 \%$ Kimchi cabbage by-products FM basis $+5 \% \mathrm{CaO}$ FM basis (TCC), and TMR $+30 \%$ Kimchi cabbage by-products FM basis $+5 \%$ CaO FM basis $+3.22 \%$ AHP FM basis (TCCA). For in vivo experiment, thirty-four Holstein steers $(273 \pm 45 \mathrm{~kg}$ ) were subjected to a 150 -day feeding trial, divided into two groups: CON and TC. In the in vitro experiment, $\mathrm{pH}$ of TCCA was greatest ( $p$ $<0.05$ ) among other treatments at all incubation times. Ammonia nitrogen and volatile fatty acid concentrations were not significantly different for each treatment. However, butyrate was greater $(p<0.05)$ in TCC and CON than in both TC and TCCA. During in situ experiment, the dry matter $(\mathrm{DM})$ disappearance was greatest $(p<0.05)$ in TCCA among other treatments. Also, disappearance of neutral detergent fiber (NDF) and acid detergent fiber (ADF) were observed greatest $(p>0.05)$ in TCCA treatment. In the in vivo experiment, average daily gain (ADG) did not differ between CON and TC. In blood profile analysis, alanine aminotransferase, aspartate aminotransferase, glucose, total cholesterol, high-density lipoprotein cholesterol, low-density lipoprotein cholesterol, and total protein concentration were not significantly different between treatments. But, creatinine concentration was greater $(p<0.05)$ in TC than 
Seon-Ho Kim

https://orcid.org/0000-0002-9350-1853

Raniel A. Valencia

https://orcid.org/0000-0002-3577-9187

Chang-Dae Jeong

https://orcid.org/0000-0001-6567-4397

Mahfuzul Islam

https://orcid.org/0000-0001-6010-140X

Chul-Ju Yang

https://orcid.org/0000-0003-3510-3096

Sang-Suk Lee

https://orcid.org/0000-0003-1540-7041

Competing interests

No potential conflict of interest relevant to

this article was reported.

Funding sources

This study was financially supported by

Korea Institute of Planning and Evaluation for

Technology in Food, Agriculture and Forestry

(IPET) (Project no. 314075-3).

Acknowledgements

Not applicable.

Availability of data and material

Upon reasonable request, the datasets

of this study can be available from the

corresponding author.

Authors' contributions

Conceptualization: Son AR, Kim SH, Lee SS.

Data curation: Son AR, Kim SH, Valencia

$\mathrm{RA}$, Jeong CD, Islam M, Yang CJ, Lee SS.

Formal analysis: Son AR, Kim SH, Valencia RA.

Methodology: Son AR, Kim SH, Jeong CD.

Software: Son AR, Valencia RA, Islam M.

Validation: Lee SS.

Investigation: Lee SS.

Writing - original draft: Son AR, Valencia RA.

Writing - review \& editing: Son AR, Kim SH,

Valencia RA, Jeong CD, Islam M, Yang

CJ, Lee SS.

Ethics approval and consent to participate All experimental procedures were performed in accordance with the Animal Experimental Guidelines provided by the Sunchon National University Institutional Animal Care and Use Committee (SCNU-IACUC), Korea. The experimental protocol was approved by the SCNU-IACUC (Approval number: SCNU IACUC-2018-01) in CON. Overall results suggest that Kimchi cabbage by-products either treated or untreated with $\mathrm{CaO}$ and AHP can be used as substitutional ingredient in TMR for Holstein steers.

Keywords: Kimchi cabbage by-products, Calcium oxide, Alkaline hydrogen peroxide, Total mixed ration

\section{INTRODUCTION}

The demand for livestock products has increased over the years; thus, a huge quantity of feed resources for livestock production is needed [1], leading to feedstuff scarcity and higher feed costs [2,3]. The use of alternative feed resources [1] and sustainable feed formulations, defined as nutritional and economic feed optimization [4], could play an important role in overcoming this challenge. Accordingly, the use of the total mixed ration (TMR) in feeding systems, which can reduce feed costs by utilizing cheap feedstuff from agricultural by-products, is an alternative to the existing production system [5] and also reduce environmental pollution [6]. By-products are also beneficial in alleviating fermentation in the rumen while providing high energy levels to the rations by means of their special chemical properties that are not acquired in ordinary feed grains or forages $[1,6]$.

The most common by-products in agriculture, specifically in Korea, are the by-products of the Kimchi cabbage (Chinese cabbage or Korean traditional Baechu) which is regarded as an important vegetable for making kimchi. From 2011 to 2017, the total annual production of both Chinese cabbage and cabbage in the country was approximately two and a half million tons, which was estimated to be the fourth-largest producer of cabbage in the world [7]. However, up to $30 \%$ of the total production is discarded as waste during the processes of production, postharvest storage, transportation, and the further processing of the Chinese cabbage $[7,8]$. The disposal rate is also very high in the wholesale market, where the cabbages are brought before their distribution to retailers or intermediate merchants [7]. Thus, several studies have been conducted that aimed at determining the efficient utilization of Chinese cabbage and its by-products as feed ingredients for ruminant diets $[7,9]$. However, the Chinese cabbage by-products has a high water content of approximately over $90 \%$, which reduces its usability as a livestock feed as it can readily be decomposed by putrefying microorganisms [7]. In addition, most agricultural by-products show poor digestibility due to the cell wall structure that protects nutrients from microbial digestion in the rumen $[10,11]$. Research throughout the years has revealed that disappearance can be improved by the addition of feed additives such as sodium hydroxide $(\mathrm{NaOH})$, which induces the breakage of the bonds between lignin and hemicellulose [10,11]. Nonetheless, it is necessary to find alternatives due to the high cost, handling hazards, and environmental pollution associated with $\mathrm{NaOH}$ [12]. Calcium hydroxide $(\mathrm{CaO})$ and alkaline hydrogen peroxide $(\mathrm{AHP})$ as alkaline agent feed additives, can be used as substitutes for $\mathrm{NaOH}$, because they can increase the digestibility and feed intake of ruminants by altering the structure of lignin removal from the lignocellulose [13-15]. Additionally, these alkali agents have been found to initiate the distension of the cellulose fibers that could upsurge the internal surface area, allowing the cellulases to contact the substrate, resulting in greater hydrolysis in the amorphous region and consequently increasing the proportion of crystalline cellulose $[13,16]$. These effects enable rumen microbes to attack the structural carbohydrates more easily; hence, greater disappearance and intake could be achieved [13]. Therefore, this study was conducted to investigate the effects of Kimchi cabbage by-products either treated or untreated with $\mathrm{CaO}$ and $\mathrm{AHP}$ as substitutional ingredient of TMR on in vitro fermentation, in situ disappearance and growth performance of Holstein steers. 


\section{MATERIALS AND METHODS}

All experimental procedures were performed in accordance with the Animal Experimental Guidelines provided by the Sunchon National University Institutional Animal Care and Use Committee (SCNU-IACUC), Korea. The experimental protocol was approved by the SCNUIACUC (Approval number: SCNU IACUC-2018-01).

\section{Preparation of experimental diet and chemical analysis}

The TMR was formulated based on the guideline of National Research Council (NRC) [17] for beef cattle and was prepared by mixing timothy hay, alfalfa hay, lupine seed, corn, corn gluten feed, whole cottonseed, tall fescue, molasses, salt, vitamin-mineral mix, protected fat, and limestone (Table 1). By-products of Kimchi cabbage were collected in Suncheon NongHyup Namdo Kimchi (Suncheon, Korea). Treatments used for the in vitro and in situ experiments include: TMR only $(\mathrm{CON})$, TMR $+30 \%$ Kimchi cabbage by-products (TC), TMR + 30\% Kimchi cabbage byproducts $+5 \% \mathrm{CaO}$ (TCC), and TMR $+30 \%$ Kimchi cabbage by-products $+5 \% \mathrm{CaO}+3.22 \%$ AHP (TCCA), fresh matter basis. The inclusion rate of alkali agents were based on Nuñez et al. [18]. For the in vivo experiments, CON and TC were used as treatments. The Kimchi cabbage byproducts ( $4.68 \%$ of dry matter $[\mathrm{DM}]$ basis) were treated with powdered $\mathrm{CaO}$ (1\% of $\mathrm{DM}$ basis) and/or AHP (0.64\% of DM basis) by manual mixing in a plastic container for approximately $1 \mathrm{~h}$. The treated Kimchi cabbage by-products were subsequently mixed with the TMR. The ingredients and chemical compositions of experimental TMRs were presented in Table 1. The chemical compositions evaluated were crude protein $(\mathrm{CP})$, crude fiber $(\mathrm{CF})$, ether extract (EE), calcium, phosphorus, neutral detergent fiber (NDF), and total digestible nutrients (TDN). Proximate analysis was performed according to the Association of Official Analytical Chemists [19] method. CF were analyzed using the method of Van Soest et al. [20].

\section{In vitro fermentation and in situ disappearance}

Cannulated Holstein with body weight of $600 \pm 47 \mathrm{~kg}$, housed at animal facility in Suncheon National University located in Suncheon-si, Jeollanam-do, Korea, was used for the in vitro and in situ experiments. Rumen fluid was collected before morning feeding and was obtained by squeezing the ruminal contents of the animal through the four layers of a surgical gauze and collected in a stainless-steel vacuum bottle. After collection, the filtrates were subsequently sealed, stored at $39^{\circ} \mathrm{C}$, and directly transported to the laboratory. The buffer used in this study consisted of (per L) 0.45 $\mathrm{g}$ dipotassium phosphate $\left(\mathrm{K}_{2} \mathrm{HPO}_{4}\right), 0.45 \mathrm{~g}$ potassium dihydrogen phosphate $\left(\mathrm{KH}_{2} \mathrm{PO}_{4}\right), 0.9 \mathrm{~g}$ ammonium sulfate $\left(\left[\mathrm{NH}_{4}\right] 2 \mathrm{SO}_{4}\right), 0.12 \mathrm{~g}$ calcium chloride dihydrate $\left(\mathrm{CaCl}_{2} \cdot 2 \mathrm{H}_{2} \mathrm{O}\right), 0.9 \mathrm{~g}$ sodium chloride $(\mathrm{NaCl}), 0.19 \mathrm{~g}$ magnesium sulfate heptahydrate $\left(\mathrm{MgSO}_{4} \cdot 7 \mathrm{H}_{2} \mathrm{O}\right), 1.0 \mathrm{~g}$ trypticase peptone, $1.0 \mathrm{~g}$ yeast extract, and $0.6 \mathrm{~g} \mathrm{~L}$-cysteine hydrochloride [21]. The prepared buffer was autoclaved for 15 min at $121^{\circ} \mathrm{C}$ and maintained in a $39^{\circ} \mathrm{C}$ water bath, adjusted to $\mathrm{pH} 6.9$ using $10 \mathrm{~N} \mathrm{NaOH}$, and dispensed anaerobically by continuous bubbling of $\mathrm{CO}_{2}$ gas. Meanwhile, the collected rumen fluid was strained again using a 4-layer surgical gauze placed in a funnel and the filtrate was allowed to flow into a 1-L graduated cylinder, with continuous bubbling of the $\mathrm{CO}_{2}$ gas. The filtrated rumen fluid was then mixed with the prepared buffer medium at a ratio of 1:3 and allowed to bubble for $30 \mathrm{~min}$. The $\mathrm{pH}$ was adjusted again to 6.9, before filling the serum bottle with the buffered rumen fluid. The serum bottle ( $160 \mathrm{~mL}$ capacity) was prepared by adding $1 \mathrm{~g}$ of weighed substrate of each treatment with three replications. One hundred milliliter of buffered rumen fluid was filled into individual serum bottles containing the substrate, under anaerobic conditions [22]. The bottles were subsequently sealed with rubber septum stoppers and aluminum caps and incubated at $39^{\circ} \mathrm{C}$ for 6 , 
Table 1. Ingredients and chemical compositions of experimental TMRs (DM basis, \%)

\begin{tabular}{|c|c|c|c|c|}
\hline & \multicolumn{4}{|c|}{ Treatments $^{11}$} \\
\hline & CON & TC & TCC & TCCA \\
\hline \multicolumn{5}{|l|}{ Ingredients } \\
\hline Timothy hay & 20.12 & 10.21 & 4.74 & 4.18 \\
\hline Alfalfa hay & 4.69 & 6.08 & 11.28 & 11.28 \\
\hline Lupine seed & 6.23 & 6.19 & 6.17 & 6.17 \\
\hline Corn & 40.42 & 40.21 & 40.07 & 39.99 \\
\hline Corn gluten feed & 16.41 & 16.33 & 16.27 & 16.27 \\
\hline Whole cottonseed & 3.02 & 3.00 & 2.99 & 2.99 \\
\hline Tall fescue & 2.85 & 7.08 & 7.06 & 7.06 \\
\hline Molasses & 5.04 & 5.01 & 5.00 & 5.00 \\
\hline Salt & 0.31 & 0.31 & 0.31 & 0.31 \\
\hline Vitamin-mineral mix $^{2)}$ & 0.28 & 0.28 & 0.28 & 0.28 \\
\hline Protected fat & 0.00 & 0.00 & 0.15 & 0.15 \\
\hline Limestone & 0.63 & 0.62 & 0.00 & 0.00 \\
\hline Kimchi cabbage byproducts & 0.00 & 4.68 & 4.68 & 4.68 \\
\hline $\mathrm{CaO}$ & 0.00 & 0.00 & 1.00 & 1.00 \\
\hline AHP & 0.00 & 0.00 & 0.00 & 0.64 \\
\hline Total & 100.00 & 100.00 & 100.00 & 100.00 \\
\hline \multicolumn{5}{|l|}{ Chemical compositions } \\
\hline DM (\% of as fed basis) & 65.65 & 66.26 & 68.80 & 69.97 \\
\hline Crude protein & 14.78 & 14.83 & 14.35 & 14.24 \\
\hline Crude fiber & 13.18 & 12.94 & 12.71 & 12.83 \\
\hline Ether extract & 4.30 & 4.20 & 4.38 & 4.32 \\
\hline Calcium & 0.50 & 0.60 & 1.21 & 1.23 \\
\hline Phosphorus & 0.30 & 0.56 & 0.56 & 0.56 \\
\hline NDF & 28.30 & 27.60 & 26.40 & 26.40 \\
\hline Total digestible nutrients & 82.90 & 82.50 & 82.71 & 82.70 \\
\hline
\end{tabular}

${ }^{11}$ TMR only (CON); TMR + 30\% Kimchi cabbage by-products (TC); TMR + 30\% Kimchi cabbage by-products + $5 \% \mathrm{CaO}$ (TCC); $\mathrm{TMR}+30 \%$ Kimchi cabbage by-products $+5 \% \mathrm{CaO}+3.22 \% \mathrm{AHP}(\mathrm{TCCA})$, fresh matter basis.

${ }^{2}$ Vitamin-mineral mix contained vit. A 2,650,000 IU, vit. D3 530,000 IU, vit. E 1,050 IU, niacin 10,000 mg, Mn 4,400 mg, Zn 4,400 mg, Fe 13,200 mg, Cu 2,200 mg, iodine 440 mg, and Co, 440 mg/kg of Grobic-DC provided from Bayer Health Care (Leverkusen, Germany).

TMR, total mixed ration; DM, dry matter; $\mathrm{CaO}$, calcium oxide; $\mathrm{AHP}$, alkaline hydrogen peroxide; NDF, neutral detergent fiber.

12 , and $24 \mathrm{~h}$ with shaking (100 rpm) [23].

Moreover, samples from each treatment were dried in an oven for $48 \mathrm{~h}$ at $80^{\circ} \mathrm{C}$ and ground to pass through a $1 \mathrm{~mm}$ screen [24]. The samples weighing $2 \mathrm{~g}$ (DM basis) were placed in nylon bags $(5 \times 10 \mathrm{~cm} ; 45 \mu \mathrm{m}$ pore size), and the bag openings were tied with nylon strings. Then, the bags were submerged in hot water $\left(39^{\circ} \mathrm{C}-40^{\circ} \mathrm{C}\right)$ for approximately $30 \mathrm{~min}$, and then deep fermentation in the rumen fistula of the cannulated animal immediately after morning feeding. The incubation times were $0,3,6,9,12$, and $24 \mathrm{~h}$, with six replications per treatment. After each incubation, the nylon bag was removed from the rumen cannula, immersed in clear water, and then washed without heating using a crude fiber analyzer (Ankom 220, Ankom Technology, Macedon, NY, USA). Samples for each incubation time were dried at $80^{\circ} \mathrm{C}$ for $48 \mathrm{~h}$ in a dry oven immediately after washing. 


\section{Analysis of in vitro rumen fermentation and in situ disappearance}

A press and sensor machine (EA-6, Laurel Electronics, Costa Mesa, CA, USA) was used to measure the total gas (TG). The $\mathrm{pH}$ was determined using the Schott ${ }^{\circledR}$ Instrumets Lab 860 (SI Analytics GmbH, Mainz, Germany) after opening each serum bottle. Samples of fermentation were also collected in $1.5 \mathrm{~mL}$ cryotubes and deep frozen at $-80^{\circ} \mathrm{C}$. These samples were later thawed at room temperature and then centrifuged at $13,000 \times \mathrm{x}$ for $15 \mathrm{~min}$ at $4^{\circ} \mathrm{C}$ using a Micro 17TR centrifuge (Hanil Science Industrial, Incheon, Korea) and the supernatant was used for ammonia nitrogen $\left(\mathrm{NH}_{3}-\mathrm{N}\right)$ and volatile fatty acids (VFA) analysis [22]. Using the Libra S22 spectrophotometer (Biochrom, Cambridge, UK) at an absorbance of $630 \mathrm{~nm}, \mathrm{NH}_{3}-\mathrm{N}$ concentration was measured according to the methods developed by Chaney and Marbach [25]. VFA were analyzed using high performance liquid chromatography (Agilent Technologies1200 series, Agilent Technologies, Santa Clara, CA, USA) with a UV detector (210 nm and $220 \mathrm{~nm}$ ) and a Metacarb87H (Agilent Technologies) column using $0.0085 \mathrm{~N} \mathrm{H}_{2} \mathrm{SO}_{4}$ as a buffer at a flow rate of $0.6 \mathrm{~mL} / \mathrm{min}$ and temperature column of $35^{\circ} \mathrm{C}$. The DM disappearance in the rumen was calculated according to the protocol of Van Emon et al. [26]. For NDF and acid detergent fiber (ADF) analysis, ANKOM 220 Fiber Analyzer (AnkomTechnology) based on the Van Soest et al. [20] method was used.

\section{Growth performance and blood profiling of Holstein steers (in vivo)}

Thirty-four heads of Holstein steers $(273 \pm 45 \mathrm{~kg})$ were used as experimental animals in this study for $150 \mathrm{~d}$; animals were housed in the farm located in Gimje-si, Jeollanam-do, Korea. The animals were selected randomly and equally distributed into two groups (CON and TC). The steers were housed in steel-constructed pens $(5 \mathrm{~m} \times 10 \mathrm{~m})$ with two or three steers per pen. The animals were fed twice a day (08:00 and 18:00) and water was made available ad libitum. The in vivo data included the body weight, average daily gain (ADG), and feed conversion ratio (FCR). We offered the same amount of TMR as group feeding ( $10 \mathrm{~kg}$ fresh matter basis/steer/d) for all steers throughout the feeding trial and no orts were observed. The ADG was calculated by subtracting the initial weight to the final weight and divided by the experimental period. The FCR was calculated by dividing the total input of the given feed by the total weight gain. At the end of the feeding trial, blood samples were collected $3 \mathrm{~h}$ after morning feeding from the jugular vein in $5 \mathrm{~mL}$ BD Vacutainer $^{\circledR}$ SST $^{\mathrm{TM}}$ II Advance (BD Vacutainer Systems, Plymouth, UK), left at room temperature for $30 \mathrm{~min}$, and subsequently centrifuged at $1,300 \times \mathrm{g}$ for $10 \mathrm{~min}$ at $4^{\circ} \mathrm{C}$ to obtain the serum. Blood parameters such as alanine aminotransferase (ALT), aspartate aminotransferase (AST), glucose, total cholesterol, high density lipoprotein (HDL) cholesterol, low density lipoprotein (LDL) cholesterol, creatinine, blood urea nitrogen (BUN), and total protein were analyzed using an automated blood biochemical analyzer (Hitachi 747, Hitachi, Tokyo, Japan).

\section{Statistical analysis}

All the data obtained in this experiment were collected for each incubation period, and statistical analysis was performed using the standard statistical analysis system (SAS) version 9.1 statistical package (SAS Institute, Cary, NC, USA). Using the general linear model (GLM), data were analyzed by analysis of variance (ANOVA). Duncan's multiple range test was used to identify differences between and among control and treatment group. To indicate significance between mean, $p<0.05$ was considered. 


\section{RESULTS AND DISCUSSION}

\section{In vitro fermentation and in situ disappearance}

The effects of different dietary treatments on $\mathrm{pH}, \mathrm{TG}, \mathrm{NH}_{3}-\mathrm{N}$, and VFA during in vitro rumen fermentation are shown in Table 2 . The in vitro $\mathrm{pH}$ was greater $(p<0.05)$ in TCCA and TCC groups at all the incubation times than the two other groups. The reason of high $\mathrm{pH}$ might be due to the influence of the alkaline substances such as $\mathrm{CaO}$ and $\mathrm{AHP}$, which were added to the Kimchi cabbage by-products. Similarly, Boukila et al. [27] reported that feeding lambs with high dietary $\mathrm{Ca}(\mathrm{OH})_{2}$ appears to delay a drop in ruminal $\mathrm{pH}$. In addition, Schroeder et al. [28] stated that diets containing supplementary $\mathrm{CaO}$ had a greater $\mathrm{pH}$ than those that did not apply any additive. This is due to the fact that $\mathrm{CaO}$ and AHP are alkaline agents [27]. Nuñez et al. [18] stated that alkalizers can neutralize acidity as well as increase the $\mathrm{pH}$. The greater $\mathrm{pH}$ of feed entering the gut may have buffered initial ruminal $\mathrm{pH}$ in cow supplied with supplementary $\mathrm{CaO}$ [28]. The amount of gas generated in all treatment groups increased with prolonged incubation time, and was greater $(p<$ 0.05) in the CON, TC, and TCC groups with $220.33 \mathrm{~mL}, 217.00 \mathrm{~mL}$, and $212.33 \mathrm{~mL}$, respectively,

Table 2. Effects of Kimchi cabbage by-products either treated or untreated with $\mathrm{CaO}$ and AHP as substitutional ingredient of TMR on in vitro pH, total gas, $\mathrm{NH}_{3}-\mathrm{N}$ and VFA concentrations of Holstein steers

\begin{tabular}{|c|c|c|c|c|c|c|c|}
\hline \multirow{2}{*}{ Item } & \multirow{2}{*}{ Time (h) } & \multicolumn{4}{|c|}{ Treatments $^{1)}$} & \multirow{2}{*}{ SEM } & \multirow{2}{*}{$p$-value } \\
\hline & & CON & TC & TCC & TCCA & & \\
\hline \multirow[t]{2}{*}{$\mathrm{pH}$} & 6 & $6.41^{\mathrm{c}}$ & $6.40^{\circ}$ & $6.49^{b}$ & $6.53^{\mathrm{a}}$ & 0.01 & $<0.01$ \\
\hline & 24 & $6.18^{\mathrm{c}}$ & $6.16^{\mathrm{c}}$ & $6.28^{\mathrm{b}}$ & $6.37^{\mathrm{a}}$ & 0.01 & $<0.01$ \\
\hline Total gas (mL) & 6 & $92.33^{\mathrm{ab}}$ & $101.33^{\mathrm{a}}$ & $80.33^{b c}$ & $76.00^{c}$ & 3.60 & $<0.01$ \\
\hline \multirow[t]{3}{*}{$\mathrm{NH}_{3}-\mathrm{N}(\mathrm{mg} / \mathrm{dL})$} & 6 & 15.51 & 15.89 & 15.36 & 13.92 & 0.68 & 0.35 \\
\hline & 12 & 17.04 & 18.29 & 16.34 & 16.90 & 0.97 & 0.60 \\
\hline & 24 & 17.42 & 18.42 & 15.90 & 16.39 & 0.48 & 0.06 \\
\hline Acetate (mM) & 6 & 35.84 & 36.33 & 36.98 & 36.60 & 0.53 & 0.57 \\
\hline \multirow{2}{*}{ Propionate (mM) } & 12 & 15.89 & 16.34 & 15.51 & 15.99 & 0.22 & 0.24 \\
\hline & 24 & 18.18 & 17.39 & 17.97 & 18.20 & 0.33 & 0.40 \\
\hline \multirow[t]{3}{*}{ Butyrate (mM) } & 6 & $8.79^{\mathrm{a}}$ & $8.28^{a}$ & $4.66^{b}$ & $4.86^{b}$ & 0.26 & $<0.01$ \\
\hline & 12 & $13.45^{\mathrm{bc}}$ & $12.35^{\mathrm{c}}$ & $17.26^{\mathrm{a}}$ & $15.30^{b}$ & 0.58 & $<0.01$ \\
\hline & 24 & $22.02^{\mathrm{a}}$ & $18.44^{b}$ & $23.54^{\mathrm{a}}$ & $18.76^{b}$ & 0.56 & $<0.01$ \\
\hline \multirow[t]{3}{*}{$A: P$ ratio } & 6 & $2.21^{\mathrm{b}}$ & $2.52^{\mathrm{ab}}$ & $2.81^{a}$ & $2.81^{a}$ & 0.08 & $<0.05$ \\
\hline & 12 & 2.53 & 2.51 & 2.51 & 2.39 & 0.06 & 0.45 \\
\hline & 24 & 2.47 & 2.60 & 2.57 & 2.62 & 0.05 & 0.39 \\
\hline Total VFA (mM) & 6 & $61.01^{a}$ & $59.07^{\mathrm{a}}$ & $54.81^{b}$ & $54.50^{b}$ & 0.68 & $<0.01$ \\
\hline
\end{tabular}

${ }^{11}$ TMR only (CON); TMR + 30\% Kimchi cabbage by-products (TC); TMR + 30\% Kimchi cabbage by-products + 5\% CaO (TCC); TMR + 30\% Kimchi cabbage by-products + 5\% CaO $+3.22 \% \mathrm{AHP}(\mathrm{TCCA})$, fresh matter basis.

${ }^{a-c}$ Means with different superscripts in the same row differ significantly $(p<0.05)$.

$\mathrm{CaO}$, calcium oxide; $\mathrm{AHP}$, alkaline hydrogen peroxide; $\mathrm{TMR}$, total mixed ration; $\mathrm{NH}_{3}-\mathrm{N}$, ammonia-nitrogen; $\mathrm{VFA}$, volatile fatty acid; $\mathrm{A}: \mathrm{P}$ ratio, acetate to propionate ratio. 
during $24 \mathrm{~h}$ incubation, than in TCCA. In the in vitro fermentation, the amount of gas generated is used as an important indicator for determining fermentation properties in the rumen along with the $\mathrm{pH}[29]$. This means that decomposition and fermentation of the substrate were effectively carried out in the course of fermentation [30]. Ammonia-nitrogen concentrations were lower in TCC and TCCA at $24 \mathrm{~h}$ of incubation with $15.90 \mathrm{mg} / \mathrm{dL}$ and $16.39 \mathrm{mg} / \mathrm{dL}$, respectively $(p>0.05)$ than in $\mathrm{CON}$ and TC. Chaudhry [31] reported that concentration of $\mathrm{NH}_{3}-\mathrm{N}$ in rumen was lower in straw treated with $\mathrm{CaO}, \mathrm{NaOH}$, and $\mathrm{NaOH}+\mathrm{AHP}$ than untreated straw. Accordingly, the decrease in the $\mathrm{NH}_{3}-\mathrm{N}$ was presumably a consequence of an increase in the available energy, and rumen microbes utilize ammonia during the enhanced degradation of straw components after chemical treatments [31]. It was reported that the $\mathrm{NH}_{3}-\mathrm{N}$ concentration should be $5 \mathrm{mg} / \mathrm{dL}$ or more to ensure and maintain maximum microbial protein synthesis [32], while the intake and disappearance of the DM are maximized when the concentration is maintained at $20 \mathrm{mg} / \mathrm{dL}$ [33]. Acetate was greater in TCCA ( $47.66 \mathrm{mM})$ after $24 \mathrm{~h}$ followed by TCC, TC, and CON with $46.12 \mathrm{mM}, 45.26$ $\mathrm{mM}$, and $44.93 \mathrm{mM}$, respectively $(p>0.05)$. In contrast, propionate was greater $(p<0.05)$ in CON and TC at $6 \mathrm{~h}$ incubation with $15.22 \mathrm{mM}$ and $14.45 \mathrm{mM}$, respectively, than TCC $(13.18 \mathrm{mM})$ and TCCA (13.04 mM). Schroeder et al. [28] reported that ruminal propionate concentration was decreased while acetate concentration was increased when $\mathrm{CaO}$ was added to the diet due to the improvement in forage fiber disappearance. On the other hand, butyrate was greater $(p<0.05)$ in TCC at 12 and $24 \mathrm{~h}$ of incubation with $17.26 \mathrm{mM}$ and $23.54 \mathrm{mM}$, respectively, than the other treatments. Nuñez et al. [18], reported that butyrate increased linearly as $\mathrm{CaO}$ inclusion increased, indicating that the efficiency of dietary energy utilization was improved by the treatment. At $24 \mathrm{~h}$ of incubation, TCCA had the greatest acetate to propionate ratio (A:P ratio), numerically, compared to the other treatment but there were no significant differences. Nuñez et al. [18] reported that the A:P ratio increased linearly with increasing $\mathrm{CaO}$ inclusion due to the increased fiber disappearance. Total VFA concentration was greater $(p<0.05)$ in TC at $6 \mathrm{~h}$ than TCC and TCCA, but was not significantly different in CON. At $24 \mathrm{~h}$ of incubation, there was no significant difference among the treatments but numerically greater in TCC. This might be due to the improved degradation of fiber with the influenced of alkaline treatment [18].

The effect of different dietary treatments on DM, NDF, and ADF disappearance through in situ experiment is shown in Table 3. The DM disappearance gradually increased in all treatments after $3 \mathrm{~h}$ of incubation, and was greater $(p<0.05)$ in TCCA with $79.53 \%$ disappearance at $24 \mathrm{~h}$ than the other treatments. Wanapat et al. [34] reported that alkaline agent like $\mathrm{CaO}$ improves DM disappearance of roughage. Moreover, Chaudry [35] reported that AHP was the most effective treatment for improving the degradation of wheat straw. According to Khejornsart et al. [14] and Carvalho et al. [15], disappearance and feed intake of ruminants can be improved by alkaline treatment because it alters the structure of lignin removed from lignocellulose. In connection with Rezende et al. [36] stated that the removal of lignin from the inside parts of the cell wall damaged and weakened the cell morphology by separating the cell bundles, thus resulting in long cellular structures which are connected in the longitudinal direction. Wanapat et al. [34] stated that the application of alkaline agents to substrates can chemically break the ester bonds of lignin, hemicellulose, and cellulose, and physically swell the structural fibers. The NDF and ADF disappearance in the TCCA treatment was numerically greater than in the other treatments after $24 \mathrm{~h}$ of incubation with $40.77 \%$ and $35.57 \%$, respectively, which indicates improvement in rumen fermentation and disappearance when $\mathrm{CaO}$ and $\mathrm{AHP}$ were added. Nuñez et al. [18] stated that the linear increase in NDF and ADF disappearance was due to the increase in $\mathrm{CaO}$ inclusion, which enhances ruminal fiber fermentation. Chaudhry [31] reported that when $\mathrm{CaO}$ and $\mathrm{AHP}$ were incorporated into rice straw, it effectively removes barriers that limit the digestion of structural 
Table 3. Effects of Kimchi cabbage by-products either treated or untreated with $\mathrm{CaO}$ and AHP as substitutional ingredient of TMR on in situ DM, NDF and ADF disappearance (\%)

\begin{tabular}{|c|c|c|c|c|c|c|c|}
\hline \multirow{2}{*}{ Item } & \multirow{2}{*}{ Time (h) } & \multicolumn{4}{|c|}{ Treatments ${ }^{1)}$} & \multirow{2}{*}{ SEM } & \multirow{2}{*}{$p$-value } \\
\hline & & CON & TC & TCC & TCCA & & \\
\hline \multirow[t]{6}{*}{ DM disappearance (\%) } & 0 & $31.16^{b}$ & $34.64^{\mathrm{a}}$ & $30.63^{b}$ & $30.15^{\mathrm{b}}$ & 0.35 & $<0.01$ \\
\hline & 3 & $53.54^{c}$ & $57.65^{\mathrm{a}}$ & $54.67^{b}$ & $53.86^{c}$ & 0.16 & $<0.01$ \\
\hline & 6 & 60.51 & 61.78 & 60.75 & 62.01 & 0.56 & 0.25 \\
\hline & 9 & $62.50^{\mathrm{bc}}$ & $64.49^{\mathrm{ab}}$ & $61.44^{c}$ & $64.98^{\mathrm{a}}$ & 0.59 & $<0.05$ \\
\hline & 12 & $63.58^{\mathrm{b}}$ & $67.85^{\mathrm{a}}$ & $64.78^{\mathrm{b}}$ & $68.14^{\mathrm{a}}$ & 0.69 & $<0.01$ \\
\hline & 24 & $72.23^{b}$ & $74.94^{b}$ & $75.12^{\mathrm{b}}$ & $79.53^{\mathrm{a}}$ & 0.93 & $<0.01$ \\
\hline \multirow[t]{5}{*}{ NDF disappearance (\%) } & 3 & 5.12 & 5.58 & 9.10 & 11.92 & 2.32 & 0.39 \\
\hline & 6 & 18.35 & 11.13 & 11.94 & 19.93 & 3.07 & 0.30 \\
\hline & 9 & 21.71 & 16.09 & 17.19 & 24.85 & 2.52 & 0.18 \\
\hline & 12 & 26.98 & 22.31 & 24.30 & 23.71 & 3.59 & 0.87 \\
\hline & 24 & 37.24 & 37.49 & 38.48 & 40.77 & 2.16 & 0.77 \\
\hline \multirow[t]{5}{*}{ ADF disappearance (\%) } & 3 & 1.98 & 3.59 & 8.18 & 6.96 & 1.80 & 0.31 \\
\hline & 6 & 10.70 & 4.08 & 13.85 & 12.90 & 3.47 & 0.50 \\
\hline & 9 & 11.41 & 7.68 & 16.87 & 15.48 & 3.31 & 0.55 \\
\hline & 12 & 12.23 & 14.95 & 19.06 & 16.10 & 2.65 & 0.48 \\
\hline & 24 & 25.68 & 24.29 & 31.14 & 35.57 & 2.45 & 0.21 \\
\hline
\end{tabular}

${ }^{1 T}$ TMR only (CON); TMR + 30\% Kimchi cabbage by-products (TC); TMR + 30\% Kimchi cabbage by-products + 5\% CaO (TCC); TMR + 30\% Kimchi cabbage by-products + 5\% CaO $+3.22 \%$ AHP (TCCA), fresh matter basis.

${ }^{a-c} M e a n s$ with different superscripts in the same row differ significantly $(p<0.05)$.

$\mathrm{CaO}$, calcium oxide; AHP, alkaline hydrogen peroxide; TMR, total mixed ration; DM, dry matter; NDF, neutral detergent fiber; ADF, acid detergent fiber; A:P ratio, acetate to propionate ratio.

carbohydrates. In addition, Castañón-Rodríguez et al. [16] revealed that supplementation with alkaline agents caused swelling of cellulose fibers that could increase the internal surface area, allowing cellulases to have direct contact with the substrates, allowing a greater level of hydrolysis in the amorphous region, and consequently increasing the proportion of crystalline cellulose. Thus, concentration of alkaline agents can effectively improve the breakdown of ester bonds between $\mathrm{NDF}$ and $\mathrm{ADF}$ and physically swollen structural fibers [37], which permits rumen microbes to breakdown the structural carbohydrates without difficulty [16].

\section{Growth performance and blood profile of Holstein steers (in vivo)}

The effect of dietary treatment on the growth performance of Holstein steers was shown in Table 4. The initial weight of the experimental animals was $273.06 \mathrm{~kg}$ in CON and $272.29 \mathrm{~kg}$ in TC. At the end of the 150-d feeding trial, the final body weight was $417.82 \mathrm{~kg}$ in CON and $413.88 \mathrm{~kg}$ in TC, but there was no significant difference. Results were the same with Song et al. [7], during their 12wk feeding trial, the final body weight of steers were not significantly different between treatments. The ADG and FCR were not significantly different between treatments. It is determined by the number of factors, such as the composition and quality of the feed [38]; thus, the greater the feed quality, the greater the ADG and FCR [39]. The effect of dietary treatments on Holstein steers blood profiles was shown in Table 5. The blood ALT, AST, and HDL cholesterol were numerically greater $(p>0.05)$ in CON with $26.00 \mathrm{U} / \mathrm{L}, 70.00 \mathrm{U} / \mathrm{L}$, and $112.71 \mathrm{mg} / \mathrm{dL}$, respectively, than in the TC group. Glucose, total cholesterol, LDL cholesterol, and total protein were numerically greater ( $p>0.05$ ) in TC with $89.47 \mathrm{mg} / \mathrm{dL}, 135.94 \mathrm{mg} / \mathrm{dL}, 25.35 \mathrm{mg} / \mathrm{dL}$, and $6.58 \mathrm{~g} / \mathrm{dL}$, respectively, than in CON. Briefly, ALT, AST, HDL, glucose, total cholesterol, LDL, and total protein were 
Table 4. Effects of Kimchi cabbage by-product as substitutional ingredient of TMR on growth performance of Holstein steers

\begin{tabular}{|c|c|c|c|c|}
\hline \multirow{2}{*}{ Items } & \multicolumn{2}{|c|}{ Treatment $^{1)}$} & \multirow{2}{*}{ SEM } & \multirow{2}{*}{$p$-value } \\
\hline & CON & $\mathrm{TC}$ & & \\
\hline Initial body weight (kg) & 273.06 & 272.29 & 5.49 & 0.92 \\
\hline Final body weight (kg) & 417.82 & 413.88 & 9.74 & 0.78 \\
\hline ADG $(\mathrm{kg})$ & 0.97 & 0.94 & 0.08 & 0.85 \\
\hline FCR & 11.74 & 11.93 & 1.10 & 0.90 \\
\hline
\end{tabular}

${ }^{1}$ TMR only (CON); TMR + 30\% Kimchi cabbage by-products (TC), fresh matter basis.

$T M R$, total mixed ration; $A D G$, average daily gain; FCR, feed conversion ratio.

Table 5. Effects of Kimchi cabbage by-product as substitutional ingredient of TMR on blood profiles of Holstein steers

\begin{tabular}{|c|c|c|c|c|}
\hline \multirow{2}{*}{ Items } & \multicolumn{2}{|c|}{ Treatment $^{1)}$} & \multirow{2}{*}{ SEM } & \multirow{2}{*}{$p$-value } \\
\hline & CON & TC & & \\
\hline $\operatorname{ALT}(U / L)$ & 26.00 & 25.71 & 0.74 & 0.78 \\
\hline AST (U/L) & 70.00 & 69.77 & 2.36 & 0.96 \\
\hline Glucose (mg/dL) & 86.18 & 89.47 & 1.74 & 0.19 \\
\hline Total cholesterol (mg/dL) & 133.24 & 135.94 & 5.53 & 0.74 \\
\hline $\mathrm{HDL}(\mathrm{mg} / \mathrm{dL})$ & 112.71 & 110.41 & 2.42 & 0.51 \\
\hline $\mathrm{LDL}(\mathrm{mg} / \mathrm{dL})$ & 23.24 & 25.35 & 1.40 & 0.30 \\
\hline Creatinine $(\mathrm{mg} / \mathrm{dL})$ & $0.80^{\mathrm{b}}$ & $0.92^{\mathrm{a}}$ & 0.04 & $<0.05$ \\
\hline $\mathrm{BUN}(\mathrm{mg} / \mathrm{dL})$ & $15.09^{\mathrm{a}}$ & $13.04^{b}$ & 0.67 & $<0.05$ \\
\hline Total protein (g/dL) & 6.31 & 6.58 & 0.10 & 0.06 \\
\hline
\end{tabular}

${ }^{1)}$ TMR only (CON); TMR + 30\% Kimchi cabbage by-products (TC), fresh matter basis.

a,b Means with different superscripts in the same row differ significantly $(p<0.05)$.

TMR, total mixed ration; ALT, alanine aminotransferase; AST, aspartate aminotransferase; HDL, high density lipoprotein; LDL, low density lipoprotein; BUN, blood urea nitrogen.

not affected by the change in TMR composition with the Kimchi cabbage by-product. Creatinine concentration was $0.92 \mathrm{mg} / \mathrm{dL}$ in TC, which was greater $(p<0.05)$ than CON group. Cao et al. [40] concluded that vegetable by-products such as Chinese cabbage have high nutritive value and in vitro DM disappearance and good potential as vegetable protein sources for ruminant, which might be the reason for the increase of creatinine concentration; since, increased protein intake contributes to greater muscle gains [41,42]. This creatinine, which is usually eliminated only via the kidneys, is produced as an end-product of muscle metabolism [43]. Costa e Silva et al. [44] reported that the increase in body weight is correlated with that of increase in creatine concentration. Thus, the relationship between muscle tissue or $\mathrm{CP}$ concentration and body weight could follow the similar relationship between the creatinine concentration and body weight [44]. Blood urea nitrogen was greater $(p<0.05)$ in the CON with $15.09 \mathrm{mg} / \mathrm{dL}$ than in the TC group. This BUN can be affected by different factors such as dietary $\mathrm{N}$-to-energy ratio, level of forage intake, and protein degradability in the rumen [45]. Wanapat et al. [34] reported that the concentration of BUN is negatively correlated to the level of production of $\mathrm{NH}_{3}-\mathrm{N}$ in the rumen, in which in the present study the production of $\mathrm{NH}_{3}-\mathrm{N}$ was numerically greater in $\mathrm{TC}$ than in the $\mathrm{CON}$ group. Protein degradation occurs more rapidly than its synthesis or the imbalances of fermentable energy and available nitrogen, and thus ammonia accumulates in the rumen fluid and be absorbed into the blood where it is transported to the liver and converted to urea [46].

In conclusion, Kimchi cabbage by-products treated with $\mathrm{CaO}$ and AHP increased in vitro 
$\mathrm{pH}$, and butyrate production. It also improved the in situ $\mathrm{DM}, \mathrm{NDF}$, and $\mathrm{ADF}$ disappearance. Moreover, $\mathrm{NH}_{3}-\mathrm{N}$, acetate, and propionate production were not hampered by $\mathrm{CaO}$ and $\mathrm{AHP}$ treatment of Kimchi cabbage by-products. ADG, FCR, and blood profiles during in vivo were not affected by the TMR substituted by Kimchi cabbage by-products, but it increased the creatinine production. Therefore, overall results suggest that Kimchi cabbage by-products either treated or untreated with $\mathrm{CaO}$ and $\mathrm{AHP}$ can be a potent substitutional ingredient of TMR for Holstein steers.

\section{REFERENCES}

1. Wadhwa M, Bakshi SPM. Utilization of fruit and vegetable wastes as livestock feed and as substrates for generation of other value-added products. Rap Publ. 2013;4:1-67.

2. Becker GS. Livestock feed costs: concerns and options. Washington, DC: Congressional Research Service; 2012.

3. Lawrence JD, Mintert J, Anderson JD, Anderson DP. Feed grains and livestock: impacts on meat supplies and prices. Choices. 2008;23:11-5.

4. Alqaisi $\mathrm{O}, \mathrm{Ndambi} \mathrm{OA}, \mathrm{Williams} \mathrm{RB}$. Time series livestock diet optimization: cost-effective broiler feed substitution using the commodity price spread approach. Agric Food Econ. 2017;5:1-9. https://doi.org/10.1186/s40100-017-0094-9

5. Kim SU, Choi YS, Yoo DJ, Ku MJ, Lee GH, Park SG. Effects of total mixed rations with corn on growth and meat quality of castrated Korean Black goats. J Korean Soc Grassl Forage Sci. 2016;36:350-6. https://doi.org/10.5333/KGFS.2016.36.4.350

6. Kajikawa H. Utilization of by-products from food processing as livestock feed in Japan. Taipei, Taiwan: Food \& Fertilizer Technology Center; 1996. p. 1-8.

7. Song KH, Woo JS, Kim JR, Ryu GL, Baek YC, Oh YK, et al. Nutritional value and in situ degradability of fruit-vegetable byproducts and their feeding effects on performance of growing Hanwoo steers. Asian-Australa J Anim Sci. 2020;33:973-80. https://doi.org/10.5713/ ajas.19.0743

8. Choi MH, Ji GE, Koh KH, Ryu YW, Jo DH, Park YH. Use of waste Chinese cabbage as a substrate for yeast biomass production. Bioresour Technol. 2002;83:251-3. https://doi. org/10.1016/S0960-8524(01)00232-2

9. Porat R, Lichter A, Terry LA, Harker R, Buzby J. Postharvest losses of fruit and vegetables during retail and in consumers' homes: quantifications, causes, and means of prevention. Postharvest Biol Technol. 2018;139:13549. https://doi.org/10.1016/j.postharvbio.2017.11.019

10. Jung HG. Forage cell wall structure and digestibility. In: Proceedings of the International Symposium on Forage Cell Wall Structure and Digestibility; 1993 Oct 7-10; Madison, Wi. p. 31546.

11. Sundstøl F, Owen E. Straw and other fibrous by products as feed. Developments in Animal and Veterinary Sciences. Amsterdam, Netherland: Elsevier; 1984.

12. Chaudhry AS, Miller EL. The effect of sodium hydroxide and alkaline hydrogen peroxide on chemical composition of wheat straw and voluntary intake, growth and digesta kinetics in store lambs. Anim Feed Sci Technol. 1996;60:69-86. https://doi.org/10.1016/0377-8401(95)009264

13. Gunun N, Wanapat M, Gunun P, Cherdthong A, Khejornsart P, Kang S. Effect of treating sugarcane bagasse with urea and calcium hydroxide on feed intake, digestibility, and rumen fermentation in beef cattle. Trop Anim Health Prod. 2016;48:1123-8. https://doi.org/10.1007/ s11250-016-1061-2 
14. Khejornsart $P$, Wanapat $M$, Rowlinson P. Diversity of anaerobic fungi and rumen fermentation characteristic in swamp buffalo and beef cattle fed on different diets. Livest Sci. 2011;139:2306. https://doi.org/10.1016/j.livsci.2011.01.011

15. Carvalho GGP, Garcia R, Pires AJV, Silva RR, Detmann E, Eustaquio Filho A, et al. Diets based on sugar cane treated with calcium oxide for lambs. Asian-Australas J Anim Sci. 2013;26:218-26. https://doi.org/10.5713/ajas.2012.12504

16. Castañón-Rodríguez JF, Welti-Chanes J, Palacios AJ, Torrestiana-Sanchez B, Ramírez De León JA, Velázquez G, et al. Influence of high pressure processing and alkaline treatment on sugarcane bagasse hydrolysis. CYTA - J Food. 2015;13:613-20. https://doi.org/10.1080/19476 337.2015.1029523

17. National Research Council [NRC]. Nutrient requirements of beef cattle: update 2000. 7th ed. Washington, DC: National Academy Press; 2000.

18. Nuñez AJC, Felix TL, Lemenager RP, Schoonmaker JP. Effect of calcium oxide inclusion in beef feedlot diets containing $60 \%$ dried distillers grains with solubles on ruminal fermentation, diet digestibility, performance, and carcass characteristics. J Anim Sci. 2014;92:3954-65. https://doi.org/10.2527/jas.2013-7501

19. AOAC [Association of Official Analytical Chemists] International. Official methods of analysis of the AOAC International. Washington, DC; AOAC International; 1995.

20. Van Soest PJ, Robertson JB, Lewis BA. Methods for dietary fiber, neutral detergent fiber, and nonstarch polysaccharides in relation to animal nutrition.J Dairy Sci. 1991;74:3583-97.https:// doi.org/10.3168/jds.S0022-0302(91)78551-2

21. Asanuma N, Iwamoto M, Hino T. Effect of the addition of fumarate on methane production by ruminal microorganisms in vitro. J Dairy Sci. 1999;82:780-7. https://doi.org/10.3168/jds. S0022-0302(99)75296-3

22. Miguel M, Mamuad L, Ramos S, Ku MJ, Jeong CD, Kim SH, et al. Effects of using different roughages in the total mixed ration inoculated with or without coculture of Lactobacillus acidophilus and Bacillus subtilis on in vitro rumen fermentation and microbial population. Anim Biosci. 2020;34:642-51. https://doi.org/10.5713/ajas.20.0386

23. Hattori K, Matsui $H$. Diversity of fumarate reducing bacteria in the bovine rumen revealed by culture dependent and independent approaches. Anaerobe. 2008;14:87-93. https://doi. org/10.1016/j.anaerobe.2007.12.002

24. Kim SH, Ramos SC, Jeong CD, Mamuad LL, Park KK, Cho YI, et al. Growth performance and blood profiles of Hanwoo steers at fattening stage fed Korean rice wine residue.J Anim Sci Technol. 2021;62:812-23. https://doi.org/10.5187/jast.2020.62.6.812

25. Chaney AL, Marbach EP. Modified reagents for determination of urea and ammonia. Clin Chem. 1962;8:130-2. https://doi.org/10.1093/clinchem/8.2.130

26. Van Emon ML, Loy DD, Hansen SL. Determining the preference, in vitro digestibility, in situ disappearance, and grower period performance of steers fed a novel algae meal derived from heterotrophic microalgae.J Anim Sci. 2015;93:3121-9. https://doi.org/10.2527/jas.2014-8654

27. Boukila B, Seoane JR, Bernier JF. Effects of dietary hydroxides on intake, digestion, rumen fermentation and acid-base balance in sheep fed a high-barley diet. Can J Anim Sci. 1995;75:35969. https://doi.org/10.4141/cjas95-055

28. Schroeder AR, Iakiviak M, Felix TL. Effects of feeding dry or modified wet distillers grains with solubles with or without supplemental calcium oxide on ruminal metabolism and microbial enzymatic activity of beef cattle. J Anim Sci. 2014;92:3997-4004. https://doi.org/10.2527/ jas.2014-7907

29. Lee KY, Kim KH, Baek YC, Ok JU, Seol YJ, Han KJ, et al. Effects of mustard seeds and pow- 
der on in vitro ruminal fermentation characteristics and methane production.J Anim Sci Technol. 2013;55:25-32. https://doi.org/10.5187/JAST.2013.55.1.25

30. Menke KH, Raab L, Salewski A, Steingass H, Fritz D, Schneider W. The estimation of the digestibility and metabolizable energy content of ruminant feedingstuffs from the gas production when they are incubated with rumen liquor in vitro. J Agric Sci. 1979;93:217-22. https://doi. org/10.1017/S0021859600086305

31. Chaudhry AS. Nutrient composition, digestion and rumen fermentation in sheep of wheat straw treated with calcium oxide, sodium hydroxide and alkaline hydrogen peroxide. Anim Feed Sci Technol. 1998;74:315-28. https://doi.org/10.1016/S0377-8401(98)00178-3

32. Satter LD, Slyter LL. Effect of ammonia concentration on rumen microbial protein production in vitro. Br J Nutr. 1974;32:199-208. https://doi.org/10.1079/BJN19740073

33. Mehrez AZ, Ørskov ER, McDonald I. Rates of rumen fermentation in relation to ammonia concentration. Br J Nutr. 1977;38:437-43. https://doi.org/10.1079/BJN19770108

34. Wanapat M, Polyorach S, Boonnop K, Mapato C, Cherdthong A. Effects of treating rice straw with urea or urea and calcium hydroxide upon intake, digestibility, rumen fermentation and milk yield of dairy cows. Livest Sci. 2009;125:238-43. https://doi.org/10.1016/j.livsci.2009.05.001

35. Chaudhry AS. Rumen degradation in sacco in sheep of wheat straw treated with calcium oxide, sodium hydroxide and sodium hydroxide plus hydrogen peroxide. Anim Feed Sci Technol. 2000;83:313-23. https://doi.org/10.1016/S0377-8401(99)00134-0

36. Rezende CA, De Lima MA, Maziero P, DeAzevedo ER, Garcia W, Polikarpov I. Chemical and morphological characterization of sugarcane bagasse submitted to a delignification process for enhanced enzymatic digestibility. Biotechnol Biofuels. 2011;4:54. https://doi. org/10.1186/1754-6834-4-54

37. Wanapat M, Cherdthong A. Use of real-time PCR technique in studying rumen cellulolytic bacteria population as affected by level of roughage in swamp buffalo. Curr Microbiol. 2009;58:2949. https://doi.org/10.1007/s00284-008-9322-6

38. Greenhalgh JFD, Wainman FW. The nutritive value of processed roughages for fattening cattle and sheep. Proc Br Soc Anim Prod. 1972;1:61-72. https://doi.org/10.1017/S030 8229600000106

39. Holechek JL, Vavra M. Forage intake by cattle on forest and grassland ranges. J Range Manag. 1982;35:737-40. https://doi.org/10.2307/3898252

40. Cao Y, Cai Y, Takahashi T, Yoshida N, Tohno M, Uegaki R, et al. Effect of lactic acid bacteria inoculant and beet pulp addition on fermentation characteristics and in vitro ruminal digestion of vegetable residue silage. J Dairy Sci. 2011;94:3902-12. https://doi.org/10.3168/jds.20103623

41. Carbone JW, Pasiakos SM. Dietary protein and muscle mass: translating science to application and health benefit. Nutrients. 2019;11:1136. https://doi.org/10.3390/nu11051136

42. Stokes T, Hector AJ, Morton RW, McGlory C, Phillips SM. Recent perspectives regarding the role of dietary protein for the promotion of muscle hypertrophy with resistance exercise training. Nutrients. 2018;10:180. https://doi.org/10.3390/nu10020180

43. Issi M, Gül Y, Başbuğ O. Evaluation of renal and hepatic functions in cattle with subclinical and clinical ketosis. Turk J Vet Anim Sci. 2016;40:47-52. https://doi.org/10.3906/vet-1505-16

44. Costa e Silva LF, Valadares Filho SC, Chizzotti ML, Rotta PP, Zanetti D, Valadares RDF, et al. Models to predict muscle tissue and crude protein in beef cattle. Livest Sci. 2014;160:18393. https://doi.org/10.1016/j.livsci.2013.11.031

45. Hammond AC, Bowers EJ, Kunkle WE, Genho PC, Moore SA, Crosby CE, et al. Use 
of blood urea nitrogen concentration to determine time and level of protein supplementation in wintering cows. Prof Anim Sci. 1994;10:24-31. https://doi.org/10.15232/S10807446(15)31923-9

46. Kim SH, Alam MJ, Gu MJ, Park KW, Jeon CO, Ha JK, et al. Effect of total mixed ration with fermented feed on ruminal in vitro fermentation, growth performance and blood characteristics of Hanwoo steers. Asian-Australas J Anim Sci. 2012;25:213-3. https://doi.org/10.5713/ ajas.2011.11186 